\title{
Conceptual problems of high-rise construction and differentiation of research within the urban environment system
}

\author{
Dmitry Korolchenko ${ }^{1, *}$ and Valery Kholshchevnikov ${ }^{1}$ \\ ${ }^{1}$ Moscow State University of Civil Engineering, Yaroslavskoe shosse, 26, Moscow, 129337, Russia
}

\begin{abstract}
The subject of this article is increased growth of the city construction with high-rise buildings of different functions. It is possible to distinguish two periods: the period of the differentiated participation of representatives from various fields of knowledge, characterized by traditional approaches and methods of each of the fields of science, and the period of integration of cross-disciplinary research, characterized by general understanding of the city as the complicated system. With respect to the system approach it is possible to distinguish several levels of hierarchy of the subsystems forming the urban environment, which provides the implementation of needs of a person and requirements of the state economy for the effective development of natural wealth and human resources. Chambers or groups of chambers, which are functionally connected depending on the way of their use in the daily cycle of multifunctional architectural - planning complex maintenance, are subdivided into four groups; each of them correspond to a special type of accumulation and movement of human flows. The analysis of movement dynamics of «entrance-exit» human flows in buildings of various types is presented. The given regularities of time dynamics of the urban population attendance of enterprise of various groups are described in the article. The lack of the aforesaid dependences, as well as the lack of necessary input data results in the inefficient project solutions, their adjustment during the maintenance requires considerable economic-and-organizational costs otherwise it is impossible in practice.
\end{abstract}

\section{Introduction}

The implications of worldwide urbanization and uncontrolled development of cities affect many aspects of society, and require a scientific approach to solving arising problems. The scientific interest in problems of cities introduced into their studying various directions and methods for the research of various aspects of urban population life, functioning of the cities within the resettlement system, their place in spatial structure of the geographical territories development as well as their influences on the ecological balance in the environment.

\footnotetext{
*Corresponding author: ICA_kbs@mgsu.ru
} 
The boom in high-rise construction in our country has experiencing a new wave. It returns us to the sea of old discussions about its expediency, in a new way, and plunges us in a tsunami of human safety problems caused by its coming. Today this discussion is especially relevant because for the whole century of history of design and construction of skyscrapers, their overall assessment remains controversial.

At the same time formation of high-rise construction in Moscow happens at obviously casual approach to the solution of the main tasks when choosing the expedient directions of development of expensive high-rise construction - placement in the city and building complexes, number of buildings, their purpose, design and composition» [1].

How some outstanding engineers and architects treat the high-rise construction? Philip Johnson: «High-rise buildings - are the constructions directed to God, power, pride symbols ... It is the impulse to appear «above all, to grasp the stars ... Skyscrapers mean the power!»

It is a very conceited statement which involuntarily reminds the bible myth about Babel tower after construction of which God has deprived the common language from people. His words were allegedly echoed by L. Sullivan: «What is the main characteristic of a high-rise office building? It's Height. It has to be high. It should be strength and Exaltation power inside it. It should contain the glory and the pride of Eminence». Here are the quotes of esthetes - I. Ehrenburg: "We have been touched by esthetics of skyscrapers»; A.-I. Huxtable: «The Skyscraper is a form of the art...It has never been any rules in design of high-rise buildings, and for each skyscraper we have many options of facades»».

But no building on the earth can be built beyond laws (rules) of nature. As for the «many options of facades», it is necessary to remember, at least, existence of dynamic proportions in architecture [2] which evaluation is defined by the psychophysics of human perception predetermining proportions of the «golden section».

As we see, conceited people and esthetes are «for» construction of the high-rise buildings. And only A. Burov is «against» it: «... On a narrow strip of the island there was a vertically reared city. ... Skyscrapers, as the prickly and dense wall ridge, have extended the entire length of Manhattan. ... It is not the scale of architecture and not of human; it is the scale of natural disaster such as wars, crisis or unemployment».

Who are these «reputable people» so admiring the skyscrapers? The first in this list becomes Philip Johnson (1906 - 2005), although he is not the first creator of American skyscrapers. This position is caused by the fact that «in the middle of ' 80 s Johnson was not only the recognized patriarch of American architecture, but also the most fashionable, most expensive, high-society and influential architect associated with the world of refined luxury and big money for many years» [3].

Initial popularity in architectural circles $\mathrm{Ph}$. Johnson received as the propagandist of the direction in modern architecture, giving preference to simple geometrical forms and designs from steel and glass, which has been named later as «international».

In subsequent years «Johnson has worked in such diverse and incomparable manners that his creativity can't be characterized by any certain stylistic terms» [3]. Examples of high-rise buildings constructed according to his projects (or projects with his participation) are given in photos (Figure 1). 


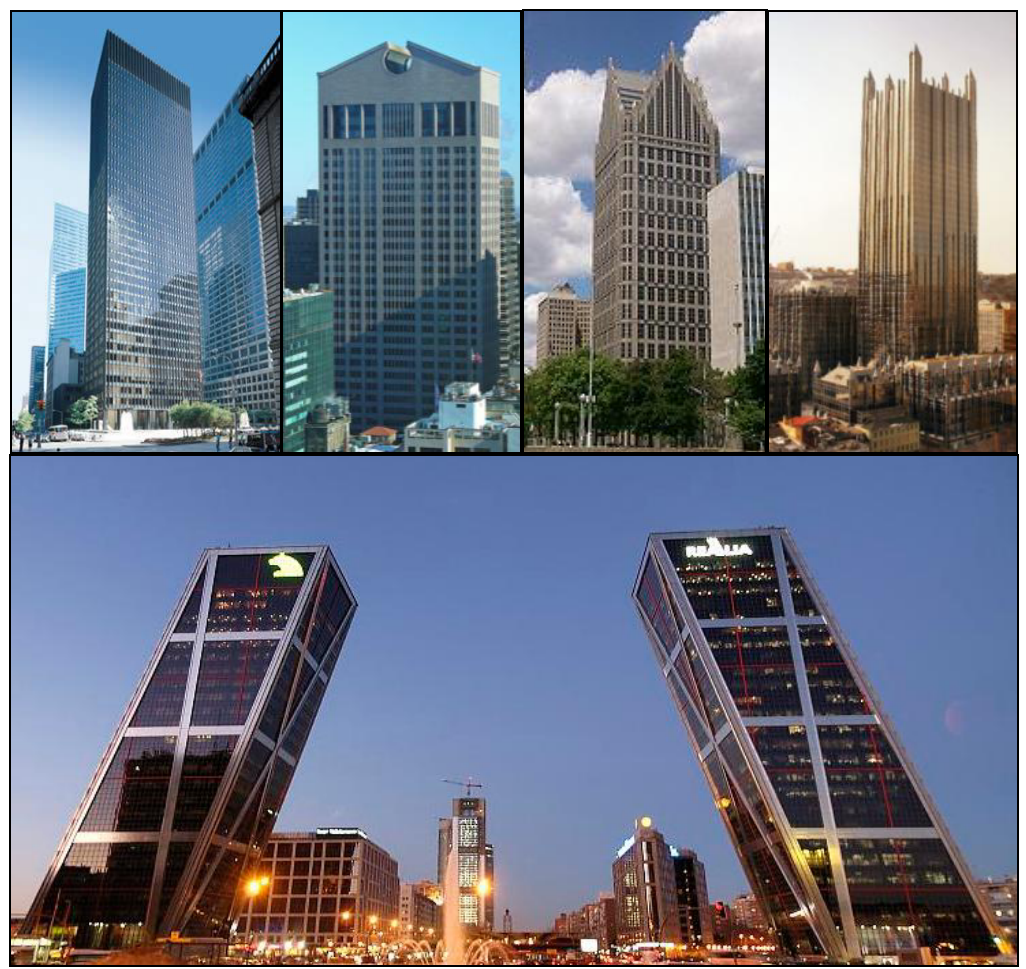

Fig.1. High-rise buildings constructed according to projects of Philip Johnson: Seagram Building, New York (1956); AT\&T (now Sony Tower), Manhattan (1984); Detroit Center on Jefferson Avenue, Detroit (1993); PPG, Pittsburgh (2007), Gate of Europe, Plaza de Castilla, Madrid (1996).

All creative activity of $\mathrm{Ph}$. Johnson is ambiguous and, often, contradictory. But such conclusion sounds quite adequately: «As the architect - Ph. Johnson - is the typical eclectic, both in the narrow professional sense, and by convictions, way of thinking. He has understood it and demonstratively emphasized: «I have always stood for the principle of non-principles». Demonstrative unscrupulousness characterizes both esthetic, and social and political views of Johnson (at initial stage Johnson even welcomed Nazism)» [3]. It didn't prevent him to become the owner of prestigious awards and expensive orders.

The second person in our list of authorities is Louis Henry Sullivan (1856-1924). He can rightfully be called the father of modern American architecture of high-rise buildings and concepts which have developed as directions called further as functionalism and organic architecture. Its leading representative was the follower of Sullivan, famous American architect Frank Lloyd Wright (1867-1959).

Louis Sullivan is the owner of an extraordinary natural artistic talent and sufficient ambition. His biographers have cited such fact. «In 1868 in Boston there was absolutely unremarkable event: the 12-year-old boy, as befits a little boy, walked around the construction site and has seen the huge, as it seemed, and very considerable person with big hat and large beard. The most fascinating was the fact that all people working at construction site treated the bearded man with great respect and were scurrying to fulfill his every order. The amazed boy asked the workers about this gentleman and heard that it is the architect. The boy has run at home and told his father that he want to become an architect. Thus was begun the career of Louis Henry Sullivan - the man who has invented the skyscraper» [4].

L. Sullivan had not finished vocational education. In 1872 he entered Massachusetts Institute of Technology, but left it soon. Then Sullivan has worked as a draftsman. In 1874 
he entered the well-known Ecole des Beaux Arts - Parisian School of fine arts which was his dream for a long time. He devoted to study about 18 hours a day. But one year later he returned to Chicago which was intensively restored after the fire, which turned the city into smouldering ruins for two days (from 8 to 10 October, 1871). In 1879 D. Adler employed L. Sullivan in his architectural bureau as a draftsman. But a year later Adler invited him to become a full partner in the firm of Adler \& Sullivan. Over 15 years of collaboration their projects have been realized in more than one hundred buildings. Two projects have defined the subsequent architectural appearance of American skyscrapers (at the end of XIX any building with height greater than 6 storeys was considered high-rise, skyscraper), Figure 2.

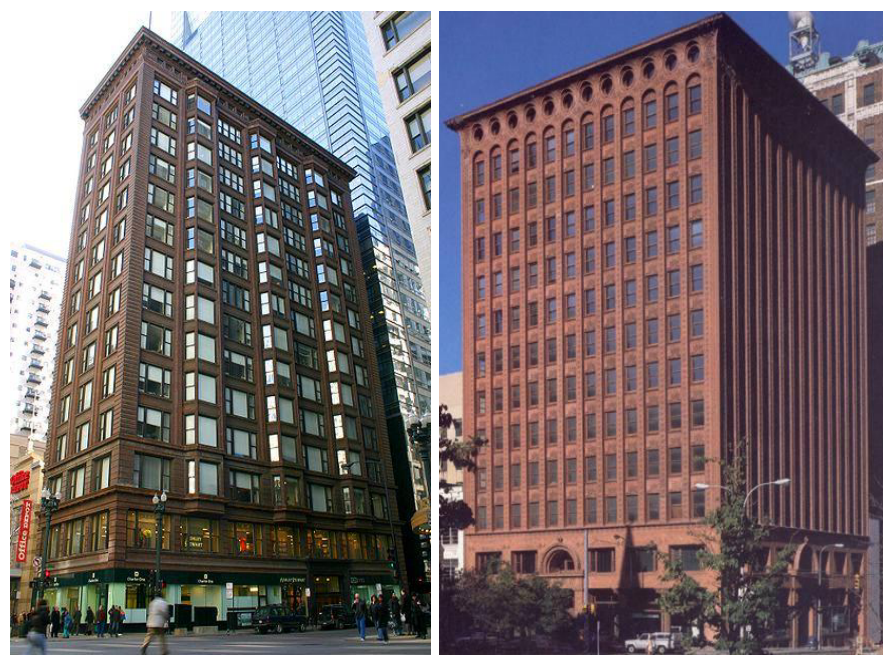

Fig.2. Buildings defined the subsequent architectural appearance of skyscrapers: Wainwright Building, St. Louis (1890-1891); Guaranty Building, Buffalo (1894-1895).

The main function of a skyscraper, according Sullivan's comprehension, is to be rather high; for this purpose building should «hover» and «aspire upwards». Wainwright Building in St. Louis has a continuous steel framework and in order to create the "soaring effect", L. Sullivan has designed the two-storeyed foundation standing on the separate columns. High vertical elements and large windows provided the effect of lightness.

One of the Sullivan's phrases has become an aphorism: «The form in architecture is defined by function». And in this sense we can read the quote from his article: «It should be strength and mightiness of height, glory and pride of exaltation in any building».

The next person in the "list of authorities» is Ilya Grigoryevich Ehrenburg (1891 1967). Ilya Grigoryevich, despite his numerous talents (writer, poet, translator from French and Spanish, publicist, photographer and etc.) has never been the professional neither in architecture, nor in construction and art history. He has been included in this list, apparently, due to popularity among particularly susceptible people - aesthetes; or as «the person estimating everything only from an aesthetic point of view and neglecting the moral part of phenomena».

Perhaps, that's why he had felt satisfaction in such situations when A. Burov had find «the scale of disaster».

The evidence of authority of such «reputable man», as A. I. Yukstabl, could not be found. It is just right to use this name as a common for people who groundlessly expressed such similar opinions.

However, the above mentioned quotations are only expressions of the ethical aura of their authors, excited by visual perception of the certain high-rise buildings. They give 
nothing for decision the primary of the main tasks discussion of which has been connected with problem of «placement in the city, planning».

And only A. Burov has given a gloomy assessment of Manhattan appearance taking into account the problem of social symbolism. Andrey Konstantinovich Burov (1900 - 1950) is the Soviet architect, Doctor of Engineering, corresponding member of the Academy of Construction and Architecture of the USSR. In 1931 he saw Manhattan for the first time (Fig. 3). The problem of «City construction» was close to him; he has designed buildings for new cities of the Post-Revolutionary Russia and later was awarded a trip to the USA. This quote expresses the main thought of architect: «the high-rise buildings are only icebergs, visible part of the massif of social, economic, environmental, technical and systematic problems of city building and planning».

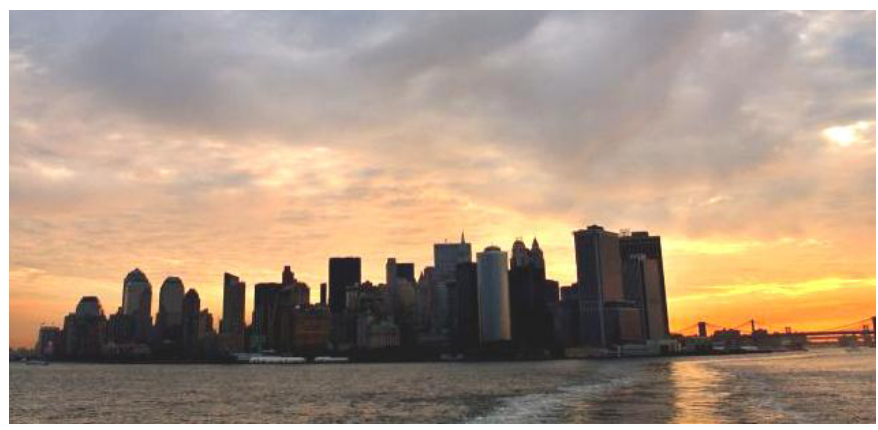

Fig.3. Lower Manhattan.

A. K. Burov is not alone in such assessment. «Even Romans tried to build higher buildings to accommodate the maximum number of occupants at the minimum area. In some sources it was claimed that one of the highest buildings was Insula Felicies, had 20 floors» [6]. (Other sources [7] give more modest figure -10 floors).

In essence, American skyscrapers are the tenement houses of XIX century: «The number of «happy» sites can be multiplied to the limit due to skyscrapers, allow selling the same land area repeatedly» [5]. Each owner of the favorable land area tries to build such high building as it possible in order to get the maximum «profitable sites» and make a good advertisement. "As the undeveloped land is the lost land for speculators, so there grow skyscrapers alongside, climbing each other. Separated by narrow small streets, high buildings take away lite, air and space from themselves and from streets turned into the dark gorge» [6].

The history of construction in Manhattan illustrates this process. «For 50-70 years the overwhelming part of buildings in Downtown Manhattan were changed three times. Every time new building was planned by both customers, and architects as potentially eternal. However the elements of free business were forced to demolish almost unamortized buildings placed on prestige land areas which price has been increased all the time: 7-9 storey buildings have been changed by 20-25 storey buildings, which after ten years have given way to 40 - 50 storey buildings» [8], and, in the future, to 100 and more storey buildings.

The New York Zoning Code (1916) was an attempt to reach the compromise between the city construction system and height of buildings growing along the streets. Construction of the 40 storey skyscraper Equitable Building (Fig. 4), which huge dimensions (it was largest in the world by total office area $-111483 \mathrm{~m}^{2}$ ) have blocked out sunlight for territory in the North, was the impetus for Zoning Code adoption. The skyscraper was constructed on a place of large trade building (Houghwout) occupied a whole city quarter (Broadway, Pine, Nassau \& Cedar street). 

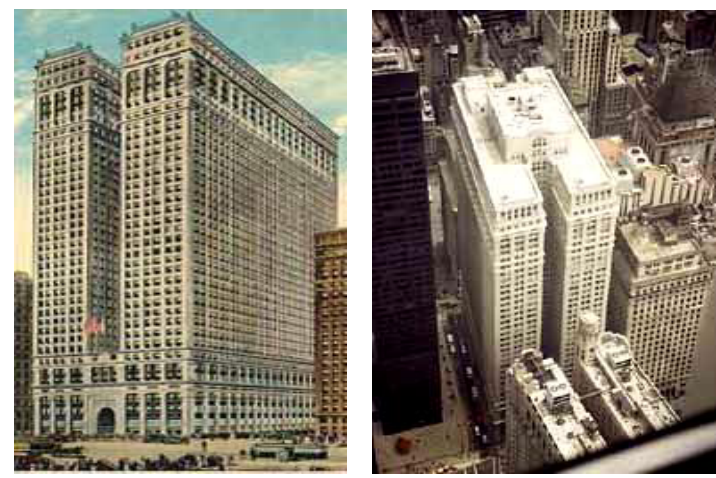

Fig. 4. Equitable Building

«In accordance with this law (Code) the height of building facade should depend on the width of street: part of the building, raised over prescribed height, should be in a form of ledges inscribed into imagined plane where the axis of street connected with the axis of upper bound of facade on its red line», Figure 5 [9].

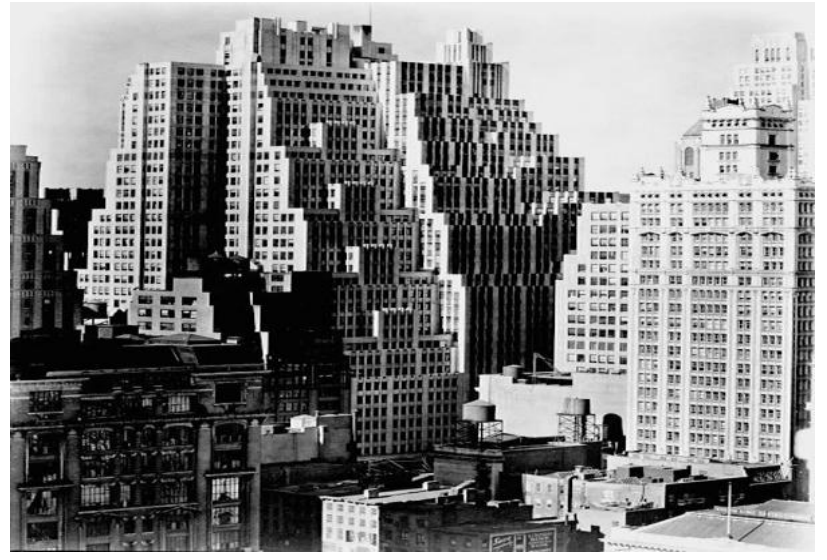

Fig.5. Example of realization of the Zoning Code in building construction.

This Code is another one official evidence of unfounded opinion of the unknown authoritative person: «We don't have... and never had any rules in design of high-rise buildings...».

Adoption of such regulations has shown that high-rise construction has inherited «ugliness» of the last century cities, with their chaotic zoning in the time of rapid industrial development. Zoning Code was the measure to mitigate the impact of this heritage on ecology of the city, exacerbating in conditions of increased construction height, using external (administrative) measures.

The «ugliness» of the last century cities has strongly «stuck» to the high-rise buildings growing everywhere and became the symbols of such cities. The idea of multistoried city has been discredited for many years, and the theory of cities - horizontal gardens is important for people loving sun, greenery and space.

The scientific interest in problems of cities, which have been becoming more active since the beginning of the world urbanization, introduced into their studying various 
directions and methods for the research of various aspects of urban population life, functioning of the cities within the resettlement system, their place in spatial structure of the geographical territories development as well as their influences on the ecological balance in the environment. Within the development of this interest, it is possible to distinguish two periods: the period of the differentiated participation of representatives from various fields of knowledge, characterized by traditional approaches and methods of each of the fields of science, and the period of integration of cross-disciplinary research, characterized by general understanding of the city as the complicated system.

Differentiation of the research of the first period not only discovered numerous new facts, ideas and directions of the development of research in each of the disciplines, participating in studying of the city life but also generated a certain professional competition between them. "Competition of disciplines, and particularly, economics, geography and sociology, while studying the problems of cities development, the district planning and improvement of the territory explains the features of the mutual estrangement, which are noticeable in case of consideration of methodology or when viewing any references» [11].

Representatives of the classical approach $[12,13]$ considered that the price of the land site in the city is equal to its agricultural cost increased by the price of benefits of its location. In case of assessment of the sites, which are already built-up it is recognized that there is a balance between the expenses of a new type of use of the land, the market value of the site and the future income of owners, i.e. there is free competition, peculiar to the simple commodity economy and to the formation of the capitalist market relations. The simple commodity production is known to be based on the private property, funds for production of goods (product) and personal labor of producer (members of his family) in the volume, which is necessary for satisfaction of his or her personal needs.

Thus, some possibilities of influence on the city planning structure appear. The matter of how they should develop in case of the proceeding intensive urbanization in the changing political-and-economic conditions and social-and-political systems, which succeed each other, still remains unsolved. The theorists of new approaches conclude, that «all the spatial organization of the city directly results from the organization of transport flows as the function of human flows» [11]. Therefore, they search a proper relation between the cost of the land sites and costs of time for the movement around the city. The evolution of approaches to forming of cost of the land sites in the city also reflects a wider range of changes in the methodology of research of the cities problems by various branches of science.

With respect to the system approach it is possible to distinguish several levels of hierarchy of the subsystems forming the urban environment, which provides the implementation of needs of a person and requirements of the state economy for the effective development of natural wealth and human resources.

The subsystems of the first (lowest) level can be called the architectural-and-planning complex (APC) which includes a set of buildings or structures and city spaces, united by a certain measure of spatial integrity and by functional coherence enters. The elements of the APC are certain buildings with their components (rooms, structures, equipment, construction site) and rather isolated territories. For example, a public center of the residential district, buildings within the intermain territory, the city park, etc. can be considered as APC. The planning structure of APC is determined by functional-and-spatial communications, which became the basis on which these elements are united into the complex.

Buildings of APC are the sources and generators of human flows. As each building and structure in the city is erected for satisfaction of certain needs of its inhabitants and for 
ensuring the interconnected functioning, the corresponding classification of buildings according to their destination is introduced.

Human needs are numerous and they can be classified according to a certain hierarchy. As a rule, three main types of requirements are distinguished: material, spiritual and social.

Chambers or groups of chambers, which are functionally connected depending on the way of their use in the daily cycle of APC maintenance, are subdivided into four groups; each of them correspond to a special type of accumulation and movement of human flows. Such classification is presented in Table 1 .

Table 1. Classification of functional blocks.

\begin{tabular}{|c|c|c|c|}
\hline Group & $\begin{array}{l}\text { Way of the use in the } \\
\text { daily cycle of functioning }\end{array}$ & $\begin{array}{l}\text { Functional types of } \\
\text { chambers }\end{array}$ & $\begin{array}{l}\text { Nature of accumulation } \\
\text { and movement of } \\
\text { human flows }\end{array}$ \\
\hline I & $\begin{array}{l}\text { The continuous use during } \\
\text { the certain period of day; } \\
\text { the main contingent are the } \\
\text { people, familiar with } \\
\text { planning of the building or } \\
\text { the functional block. }\end{array}$ & $\begin{array}{l}\text { Organizations of } \\
\text { management, scientific } \\
\text { and project organizations, } \\
\text { educational institutions } \\
\text { and industrial enterprises. }\end{array}$ & $\begin{array}{l}\text { Pronounced entrance and } \\
\text { exit "peaks"; relative } \\
\text { peaks in certain hours, } \\
\text { the membership of the } \\
\text { flow is generally } \\
\text { constant. }\end{array}$ \\
\hline II & $\begin{array}{l}\text { The continuous use during } \\
\text { the certain period of day; } \\
\text { the main contingent are } \\
\text { visitors, whose number } \\
\text { considerably exceeds the } \\
\text { number of permanent staff; } \\
\text { acquaintance of the main } \\
\text { contingent to the planning } \\
\text { is superficial. }\end{array}$ & $\begin{array}{l}\text { The enterprises of the } \\
\text { population service } \\
\text { industries: trade, public } \\
\text { catering; consumer and } \\
\text { public service; polyclinics } \\
\text { and out-patient clinics; } \\
\text { sports-and-improving } \\
\text { centers. }\end{array}$ & $\begin{array}{l}\text { The human flow is } \\
\text { continuous, but non- } \\
\text { uniform, it has variable } \\
\text { membership. }\end{array}$ \\
\hline III & $\begin{array}{l}\text { Mass stay of people } \\
\text { during certain periods of a } \\
\text { day. The number of places } \\
\text { for visitors is limited. } \\
\text { Acquaintance to planning } \\
\text { is limited. }\end{array}$ & $\begin{array}{l}\text { The enterprises, } \\
\text { organizing spectacular } \\
\text { and entertaining actions, } \\
\text { rest and leisure, cultural- } \\
\text { and-educational } \\
\text { institutions. }\end{array}$ & $\begin{array}{l}\text { Cyclic human flow with } \\
\text { more than } 3 \\
\text { representations, } \\
\text { incidental flow with } \\
\text { smaller number of } \\
\text { representations; variable } \\
\text { membership. }\end{array}$ \\
\hline IV & $\begin{array}{l}\text { Stay of people during a } \\
\text { short period of time; } \\
\text { acquaintance to planning } \\
\text { depends on whether they } \\
\text { work in this building or on } \\
\text { the frequency of the use. }\end{array}$ & $\begin{array}{l}\text { Railway stations, bus } \\
\text { stations, airports, transfer } \\
\text { transport hubs }\end{array}$ & $\begin{array}{l}\text { The human stream } \\
\text { depends on working } \\
\text { hours of the institutions } \\
\text { under service and on the } \\
\text { quality of transport } \\
\text { system functioning in the } \\
\text { city. }\end{array}$ \\
\hline
\end{tabular}

Parts of the building and chambers with institutions of the group I are the main for highrise buildings of business centers, such as «Moscow - City». There the human flows with pronounced «peaks» in time are formed. The distribution of number of entrance and exit 
flows in certain intervals of time received according to domestic (Figure 6) and foreign (Figure 7) researchers have identical character [14-19].

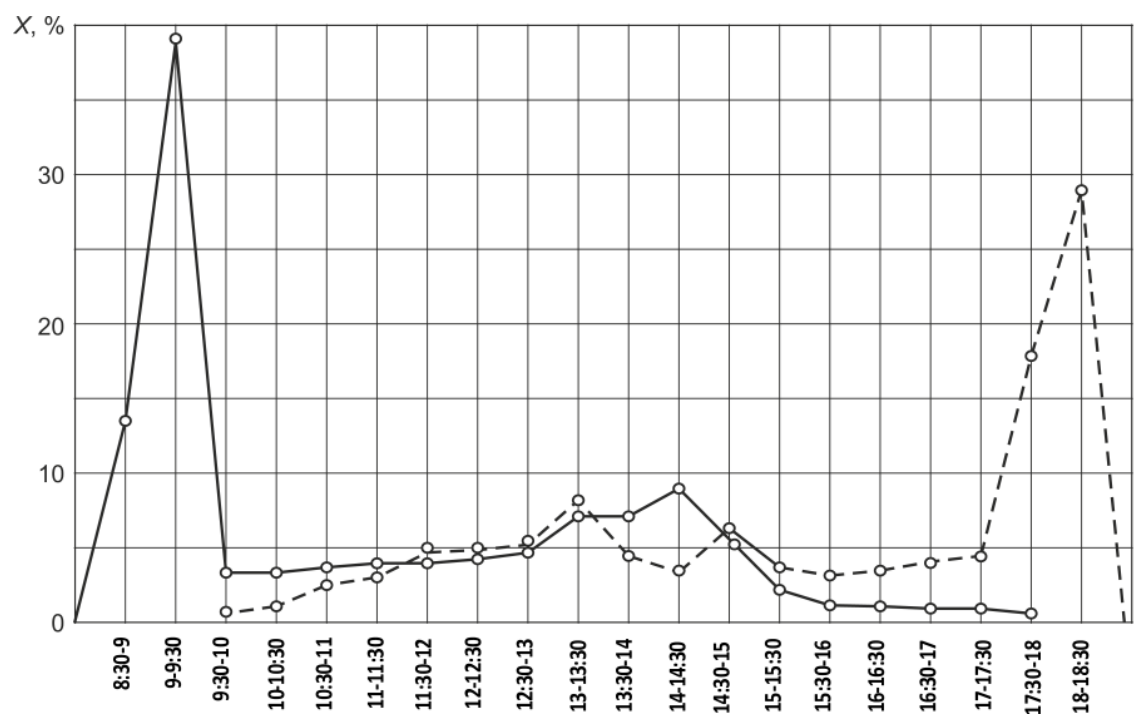

Fig. 6. Schedules of dynamics of movement, the human entrance and exit flows from buildings of the large design organizations in Moscow during the period of their functioning: ( ) - entrance, ( ----- ) - exit. Flow size (x \%) presented on the schedules is the relation of number of people $\left(\mathrm{N}_{\mathrm{t}}\right)$ coming for $(\Delta t)$ time interval, to total of people of $(\mathrm{N})$ passing for the daily period of functioning of the building, expressed as percentage.

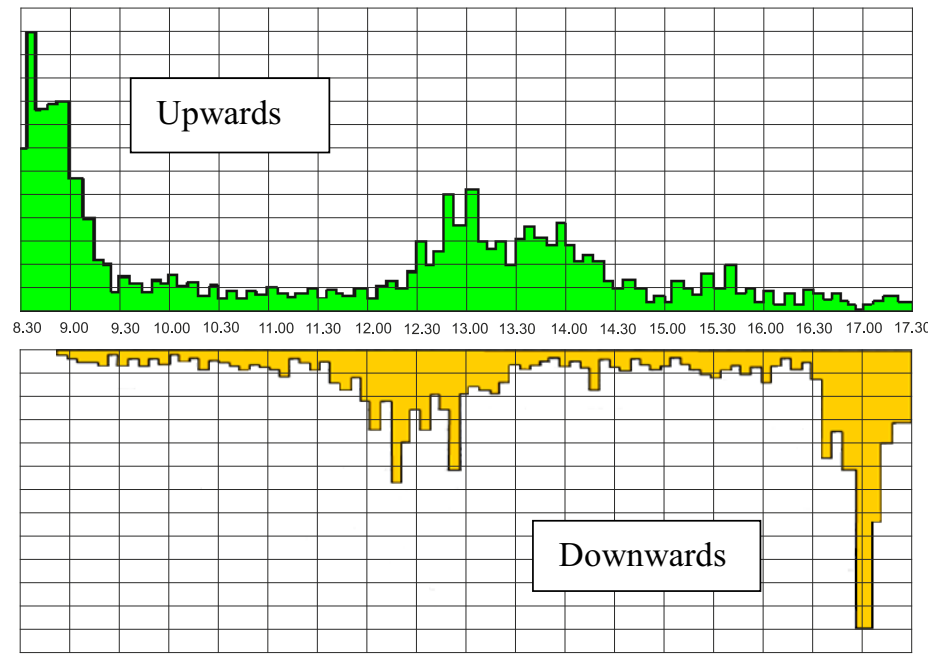

Fig. 7. The diagram of dynamics of a human entrance and exit flow from buildings of large institutions. Five-minute passenger traffics in elevators according to foreign researches.

As the schedules in the figures show, there are two typical maximum peaks:

- morning entrance "peak" before the working day;

- evening exit "peak" in the end of the working day. 
Movement of human "entrance" and "exit" flows in organizations of group II has rather uniform nature during the working day or one "peak" interval, which is as a rule matching with hours of work finishing in the organizations of group I (Fig. 8). In the trade institutions of the group the dynamics of inflow of buyers is corresponding to the goods turnover of the enterprises, this information can be used for the determination of attendance of organization if any special data are absent.

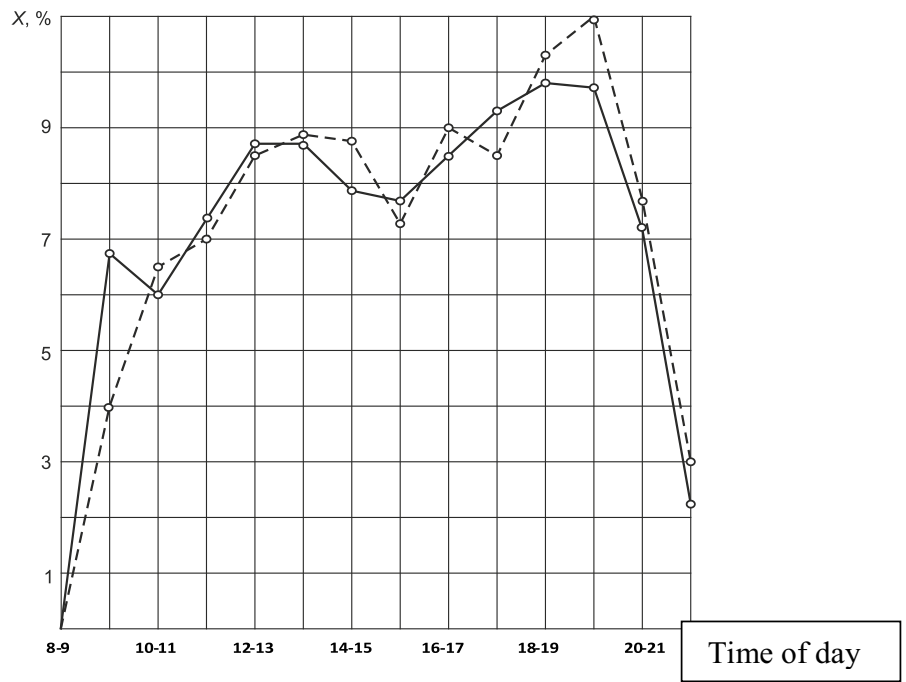

Fig. 8. Schedules of dynamics of entrance-and-exit of human flows in the building of the city main post-office in its working hours for the population.

The structure of group II differs very much according to the organizations type and their services importance in the balance of time expenses of various groups of population. These aspects also determine the dynamics of visits of organizations in their working hours; that can be noticed thanks to the comparative analysis of the "entrance exit" schedules for the corresponding types of the organizations of the group presented in the Figure 9.

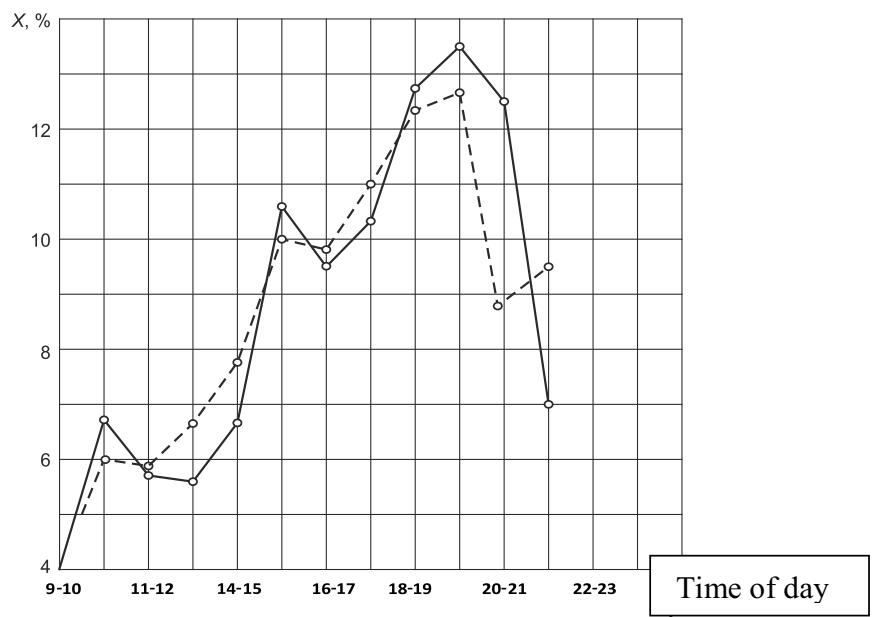

Fig. 9. The schedule of dynamics of entrance (__ $)$-and-exit ( ------ ) human flows in one of the central department stores of the city. 
One should mention the fact that the peak of attendance of the organizations, which provide services (goods) of daily demand and which are located on the way of movement of people from work to their dwelling falls on time of the end of the working day of the population occupied in the organizations of group I. Among the organizations of group II the mode of movement of human flows in the chambers and parts of buildings of catering is of special interest. The need of access control in the zones of high-rise buildings of business appointment, occupied by the organizations of group I forces to divide the catering enterprises into two groups: those, serving employees and visitors of the organizations of group I and those working for the city, i.e. serving the people who can be in the multipurpose center with their cultural and household purposes.

The schedule of the maximum loading of the enterprises of the first subgroup will reflect the dynamics of the day exit "peak" for the employees of the organizations of group I, served by them. The process of movement of the human "entrance" flow within the second subgroup (catering) is also characterized by some unevenness. The flow usually reaches its maximum value (about 11\%) from 12 to 14 o'clock, then it gradually decreases to $5-6 \%$ by $18-19$ o'clock.

Chambers and zones of buildings of the institutions of group III are divided into two groups depending on the number of the sessions, held during the period of their daily functioning from the point of view of accumulation of human flows.

The number of sessions in the chambers of the first subgroup is 1-3 a day and the number of visitors during each session is considerable. It is characteristic that because of exclusiveness of the held events as well as because of the great spectator interest the acquisition of tickets for such visits is completed in advance (several days before), and the sale of tickets in cash desks of the organization just before the beginning of a session can be absent. It is also necessary to consider that before the session accumulation of people (a crowd), interested in buying up tickets for the session or waiting for the members of their company with which they had agreed to visit this action can be formed in front of the entrance. The observed maximum size of accumulation is during $10-15$ minutes prior to representation and makes up $10-15 \%$ of the capacity of theatres and concert halls and $5-$ $7 \%$ of the capacity of sporting and spectacular halls.

Transport buildings and structures (institutions of group IV) are the intermediate link in the chain of movement of people to their destination. Therefore the nature of accumulation and generation of human flows in these institutions differs in time and depends on the mode of their functioning, their location and other numerous factors, which can be hardly considered [20-23]. The mathematical expectation for the volume of the flow at the considered subjects of transport services is defined as the sum of multiplication of all the possible values of random variable for the flow $\left(X_{i}\right)$ from the direction (i) and the probability $\left(p_{i}\right)$, i.e. as following:

$$
M[X]=\sum_{u=1}^{m} X_{i}^{t} p_{i}^{t},
$$

Where $X_{i}^{t}$ is measured as \% of amount of transfers in the considered time interval $(t)$ from daily volume of the passenger traffic in the direction $(i)$.

\section{Conclusions}

The given regularities of time dynamics of the urban population attendance of enterprise of various groups are described in the article. These regularities revealed by special research are not well-known to the wide range of specialists. The lack of the aforesaid dependences, 
as well as the lack of necessary input data results in the inefficient project solutions, their adjustment during the maintenance requires considerable economic-and-organizational costs otherwise it is impossible in practice.

\section{References}

1. T.G. Maklakova, Vysotnye zdaniia (Moscow, Assotsiatsii stroitel'nykh vuzov, 2006)

2. D. Hembidzh, Dynamical symmetry in architecture (BAA, Moscow, 1936)

3. D. K. Samin, 100 great architects (Veche pbl., Moscow, 2001)

4. L. Sullivan, http://trv-science.ru/2015/12/08/arkhitektor-louis-sullivan/ (2015)

5. M. Ragon, Modern architecture (State Publishing House of Literature on construction and architecture, Moscow, 1961)

6. V. Shuler, Konstruktsii vysotnykh zdanii (Stroiizdat, Moscow, 1979)

7. P. G. Buga, Peshekhodnoye dvizheniye v gorodakh (Stroyizdat, Moscow, 1979)

8. A. Marshall, Principle of Economics (Macmillan and Co., London, 1890)

9. E. Howard, Garden cities of Tomorrow (Faber and Faber, London, 1946)

10. J. A. Schumpeter, History of economic analysis (New economic school, St. Petersburg, 2004)

11. P. Merlin, Gorod. Kolichestvenniye metody izucheniya (Progress Publ., Moscow, 1977)

12. A. Smith, Research on the nature and reasons of wealth of nations (Eksmo pbl., Moscow, 2007)

13. H. George, Our Land and Land Policy: Speeches (Page \& Co., New York, 1900)

14. U. Izard, Methods of regional analysis: introduction to the science of regions (Progress pbl., Moscow, 1966)

15. P. Huggett, Spatial analysis in economic geography (Progress pbl., Moscow, 1968)

16. P.G. Buga, Research of pedestrian movement in cities (MISI publ., Moscow, 1973)

17. D.A. Korolchenko, A.F. Sharovarnikov, A.V. Byakov, Advanced Materials Research 1073-1076, 2353-2357 (2015)

18. A.F. Sharovarnikov, D.A. Korolchenko, AMM 475-476, 1344-1350 (2014)

19. D. Korolchenko, S. Voevoda, MATEC 86, 04038 DOI: $10.1051 /$ matecconf $/ 20168604038$

20. A.P. Parfenenko, Advanced Materials Research 1073-1076, 1551-1556 (2014) DOI: 10.4028/www.scientific.net/AMR.1073-1076.1551

21. V.V. Holshevnikov, A.N. Giletich, D.V. Ushakov, A.P. Parfenenko, Pozharovzryvobezopasnost-Fire and Explosion Safety 20(12), 32-41 (2011)

22. S. Popović, S. Vlahović, N. Vatin, Procedia Engineering, 117, 854-863, (2015), DOI 10.1016/j.proeng.2015.08.151

23. G. Radovic, V. Murgul, N. Vatin, AMM, 641-642, 634-638, (2014), DOI 10.4028/www.scientific.net/AMM.641-642.634 